\title{
Working in the 21st Century. The Coronavirus Crisis: A Driver of Digitalisation, Teleworking, and Innovation, with Unintended Social Consequences
}

\author{
Antonio López Peláez ${ }^{1}$, Amaya Erro-Garcés ${ }^{2, *(D)}$, Francisco Javier Pinilla García ${ }^{3, *}$ and Dimitrios Kiriakou 4 \\ 1 Department of Law, Campus Arrosadia s/n, National Distance Education University (UNED), \\ 31006 Pamplona, Spain; alopez@der.uned.es \\ 2 Department of Business Administration, Campus Arrosadia s/n, Public University of Navarre (UPNA), \\ 31006 Pamplona, Spain \\ 3 Instituto Nacional de Seguridad y Salud en el Trabajo (INSST), 28027 Torrelaguna, Spain \\ 4 National Council for Technology and Innovation, Greece \& New Economic Theory Working Group, \\ World Academy of Art \& Science, GR-10673 Athens, Greece; dim.kyr6@gmail.com \\ * Correspondence: amaya.erro@unavarra.es (A.E.-G.); javier.pinilla@insst.mites.gob.es (F.J.P.G.); \\ Tel.: +34-948-166-081 (A.E.-G.)
}

\section{check for}

updates

Citation: López Peláez, A.; Erro-Garcés, A.; Pinilla García, F.J.; Kiriakou, D. Working in the 21st Century. The Coronavirus Crisis: A Driver of Digitalisation, Teleworking, and Innovation, with Unintended Social Consequences. Information 2021, 12, 377. https://doi.org/ 10.3390/info12090377

Academic Editors: Hepu Deng, Richard Tay and Sophia Duan

Received: 11 August 2021

Accepted: 15 September 2021

Published: 17 September 2021

Publisher's Note: MDPI stays neutral with regard to jurisdictional claims in published maps and institutional affiliations.

Copyright: (c) 2021 by the authors. Licensee MDPI, Basel, Switzerland. This article is an open access article distributed under the terms and conditions of the Creative Commons Attribution (CC BY) license (https:// creativecommons.org/licenses/by/ $4.0 /)$.
Abstract: (1) Background: This article seeks to shed a light on the innovation, digitalisation, and teleworking processes that have occurred because of the coronavirus crisis. (2) Methods: To this end, we analyse data from Eurostat (2020), the European Companies Survey $(2013 ; 2019)$ and the Living, Working and COVID-19 Dataset (2020), the latter two gathered by Eurofound. (3) Results: Our main findings reveal that COVID-19 has accelerated a process of digitalisation that has produced relevant changes in labour relations and, consequently, in companies' organisation. (4) Conclusions: In short, home confinement has had a profound impact on work and occupational risks.

Keywords: digitalisation; teleworking; coronavirus crisis; innovation; acceleration process; occupational risks

\section{Introduction}

The coronavirus pandemic is having a profound impact, with far-reaching implications for the way people live and work across Europe and all around the world [1,2]. From the perspective of the sociology of work and organisations, COVID-19 has been managed with two complementary strategies: home confinement of the population as a health strategy and teleworking as an organisational strategy [3,4].

Companies have been forced to innovate and digitise their operative activities in a context characterised by a low level of innovation, such as the Spanish situation where innovative management practices are similar to the European path, although the 2008 economic crisis affected the Spanish economy to a greater extent than other European economies [5,6].

Although innovation fosters well-being [7,8], the confluence of these circumstances has driven a non-reversible and accelerated process of digitalisation with unintended social consequences. In this context of accelerated social change, from the perspective of the sociology of work, it is necessary to consider not only the strategies for adaptation to confinement, but also new emerging risks. In this case, the occupational risks associated with teleworking have been generalised [9].

Since the COVID-19 outbreak, there has been a reorganisation of work based on digitalisation and teleworking. Domestic spaces have been transformed into workplaces for large numbers of the working population, especially in the case of highly qualified workers and those engaged in highly value-added tasks [1,2]. Although teleworking had affected just a small percentage of employees in Europe in previous years [10], there is a 
good deal of literature on its potential negative effects on professional careers, psychosocial risks such as burnout of teleworkers, and recommendations to deal with these effects [11,12]. Nevertheless, the generalisation of telework during the home confinement and the need for digitalisation imply an accelerated transformation process in many sectors [1,2].

The present study seeks to shed a light on the innovation, digitalisation, and teleworking practices in the period of coronavirus confinement that have led to a process of accelerated change. To this end, data from Eurostat (2020), the European Companies Survey $(2013 ; 2019)$ and the Living, Working and COVID-19 Dataset (2020) have been analysed. Concretely, pre-COVID-19 and post-pandemic data are compared in order to identify main differences.

There is a plethora of literature on teleworking, but little research has focused on the impact of digitalisation in social fields and social challenges that come from digital transformation. To bridge this gap in the literature, the present study aims to review (1) effects and presence of innovation, digitalisation, and teleworking and their evolution; (2) data on COVID-19 in this area; (3) social challenges of increased digitalisation, both in the area of sustainable work (more innovation and digitalisation is required to survive, and more digital skills are needed) as well as of occupational risks; and (4) suggesting a model of labour relations adapted to an environment of teleworking and accelerated digitalisation that will be maintained over time. To this end, a comprehensive literature review of major scientific contributions made so far in this research area is undertaken.

To address these purposes, the study is organised as follows. Section 2 describes the materials and methods. Section 3 outlines the main results and discusses the findings. The study ends with the main conclusions.

\section{Research Methodology}

In a context in which the telework strategy has become mandatory, our interest lies in studying the innovation and digitalisation derived from the modality of teleworking.

We consider that teleworking practices imply digital innovation in companies and even a different way of approaching the organisation. In this context, our research question is how innovation and digitalisation occur in this pandemic environment, and how it affects labour relations. For this purpose, the data related to the innovation process have been consulted in different official statistical sources, and they have been compared to the relevant changes produced by COVID-19.

Concretely, questions related to innovation and teleworking in Eurostat (2020), the European Companies Survey $(2013 ; 2019)$ and the Living, Working and COVID-19 Dataset (2020) have been analysed to solve the research question. Information about new products and services, changes in products and services, innovation in processes and organisational marketing innovation have been consulted to find main changes derived from the pandemic.

From this data, we have responded to the research question.

\section{Materials}

This section discusses innovation and digitalisation in companies and teleworking in the context of previous years and points out some problems and the resistance to these processes. Pre-COVID-19 and current data are provided. Information is based on data from Eurostat (2019), the European Companies Survey (ECS; 2013, 2019) and the Living, Working and COVID-19 Dataset (2020); the latter two are from Eurofound.

\subsection{Flexibility and Organisation}

One of the paradoxes of our economy is the coexistence of discourses that anticipate a new era of flexibility, innovation, teamwork, and digitalisation and an economy in which many traditional organisational strategies pertain [13]. Innovation and digitalisation are the responses of companies to the new challenges of a society in constant technological transformation. The pandemic has acted as a driving force behind a trend of change that had already been visible previously. Research on teleworking, network businesses, and 
digitalisation (from digital marketing to the incorporation of automation systems and robotics) has highlighted both the accessibility and usefulness of these developments.

The COVID-19 pandemic and the global lockdown have confronted us with organisational, cultural, and technological barriers that before 2020 led to the implementation of low intensity telework, which was not in line with the expectations of scholars such as [14]. In a context in which the accessibility and the usefulness gaps were being replaced by the analysis of digital competences in advanced economies, the generalised lockdown has once again highlighted the asymmetry of conditions (e.g., in terms of geographical location, the broadband network, and the size and availability of connection in homes that have become workplaces, amongst others), and of course, the relevance of digital competences required to take advantage of the potential of teleworking.

It is for this reason that our objective is focused on the analysis of the adaptation strategies of companies in the context of a generalised lockdown, which has redefined the organisational context where teleworking and digitalisation become a survival strategy, beyond their advantages in relation to organisational flexibility or productivity. The present study allows us to rediscover the hidden potential in teleworking, in accordance with [15]. It is examined as a strategic activity that ensures the continuity of business activities in a confined environment, and not just as a flexibility strategy [4].

Flexibility allows organisations to adapt to a changing (and, as the COVID-19 has showed, sometimes unpredictable) environment. Companies can perform this adaptation process through external strategies, which are mainly based on using other firms to develop a new activity (such as outsourcing or the use of self-employed workers). Alternatively, organisations may resort to internal functional strategies (such as rotation or working teams), contractual internal strategies (part-time workers or temporary employees), internal strategies related to working time (such as overtime, working on rotating shifts, or night shifts), and internal strategies related to payment (such as pay for performance schemes, or PFP).

From the perspective of the flexibility of organisations, Ref. [16] differentiates three objectives. First, the interests of the company, which are increasingly focused on the shareholders, and are thereby seeking the creation of value for their benefit. Second, the definition of the core activity of the company, which outsources those activities not considered essential (and as such, outsourcing appears as a flexibility strategy). Third, the action of working in the company, which leads to designing high-performance practices. Hence, teleworking is considered a flexibility strategy that can, amongst having other positive impacts, favour balancing time management and commitment between family and work; Further, it can also reduce costs associated with the workplace (offices) and the mobility of workers, and expand customer service possibilities by incorporating people who work remotely from various locations and at different times.

However, the pandemic and the resulting lockdown have transformed the context in which business activities take place. Home confinement has led to an expansion of activities carried out from home, which is now an extension of the workplace. The readaptation of activities, meetings through digital platforms such as Zoom, Microsoft Teams, or Google Meet, and the redesign of administrative procedures to encourage activities to be carried out remotely, have allowed for the adaptation of strategic sectors such as education and public administration. It is an acceleration that starts from a process of flexibility and the adaptation of companies in Europe and that is characterised (Table 1) by technological innovation in the industrial sector and a reorganisation of the tasks that workers perform. In this sense, teleworking is increasing a response to confinement, but within a process of technological innovation and building on previous organisational change in European companies.

Confinement has tested digital technologies' ability to support an increasing percentage of activities performed remotely from home. The pandemic is evidently a highly uncommon context; nevertheless, one cannot rule out its re-emergence in the coming future. Within a general trend towards investment in technology and the reorganisation of 
working hours, the pandemic has accelerated the incorporation of teleworking as a strategy to ensure business continuity [4]. Some of the consequences, as will be highlighted in the concluding section, relate to the redefinition of the home as a working space, to training in the digital competences of workers, to the equipment and the availability of internet connectivity. They also reflect the organisational challenges that involve managing teams whose members are working remotely, without forgetting the occupational risks, especially those of a psychosocial nature, which are generated in this new setup.

Table 1. Organisational changes in EU-28 working centres during 2010-2013, according to activity sector and workforce size (in percentage).

\begin{tabular}{|c|c|c|c|c|c|c|c|c|c|c|}
\hline Organisational Changes & Industry & Construction & $\begin{array}{l}\text { Trade and } \\
\text { Hospitality }\end{array}$ & $\begin{array}{l}\text { Communication } \\
\text { and Transportation }\end{array}$ & $\begin{array}{l}\text { Financial } \\
\text { Services }\end{array}$ & $\begin{array}{l}\text { Other } \\
\text { Services }\end{array}$ & Total & $10-49$ & $50-249$ & $250+$ \\
\hline Remuneration system & 27.7 & 29.4 & 27.7 & 31.7 & 31.0 & 27.6 & 28.2 & 27.5 & 32.3 & 30.0 \\
\hline Use of technology & 43.7 & 40.1 & 39.9 & 40.4 & 39.3 & 44.1 & 41.9 & 40.6 & 49.0 & 52.8 \\
\hline $\begin{array}{l}\text { Allocation of tasks } \\
\text { among employees }\end{array}$ & 32.9 & 31.0 & 32.8 & 34.2 & 35.2 & 33.2 & 32.9 & 32.5 & 35.2 & 34.2 \\
\hline $\begin{array}{l}\text { Working time } \\
\text { arrangements } \\
\text { entry }\end{array}$ & 16.2 & 16.1 & 20.5 & 18.2 & 13.4 & 17.8 & 17.9 & 17.4 & 20.5 & $21.9^{1}$ \\
\hline
\end{tabular}

${ }^{1}$ Note: Total workplaces with 10 or more employees $(N=23,672)$. Source: Third European Company Survey (Eurofound, 2013).

\subsection{Teleworking}

Teleworking is generally defined as the use of new information and communication technologies (ICTs) for the purposes of work outside the employer's premises. Advanced ICTs facilitate working across time, space, and organisational boundaries [17].

The following section presents data on teleworking across Europe before and after the pandemic. Data from Eurostat are analysed to describe the situation concerning remote working before the pandemic, and a survey from Eurofound is used to identify the increase in teleworking in the lockdown and beyond.

Table 2 presents the evolution of employed persons working from home as a percentage of total employment in Europe before COVID-19.

Table 2. Teleworking in Europe pre-COVID-19.

\begin{tabular}{ccc}
\hline Year & $\begin{array}{c}\text { European Union } \\
\mathbf{( 2 0 1 3 - 2 0 2 0 )} \\
\text { Frequency } \\
\text { Usually }\end{array}$ & 25 Countries \\
\hline 2008 & 4.7 & Sometimes \\
2009 & 4.6 & 7.7 \\
2010 & 4.8 & 7.8 \\
2011 & 5.2 & 8.1 \\
2012 & 5.2 & 7.9 \\
2013 & 4.7 & 8.2 \\
2014 & 4.7 & 8.8 \\
2015 & 4.7 & 8.8 \\
2016 & 4.7 & 9.8 \\
2017 & 5.0 & 9.9 \\
2018 & 5.1 & 9.7 \\
2019 & 5.3 & 9.9 \\
2008 & 4.7 & 10.8 \\
\hline
\end{tabular}

${ }^{2}$ Source: Eurostat (2019).

As can be observed, there was only a small increase in the number of workers who usually worked at home between 2008 and 2019 (from 4.7\% to 5.3\%). The figure for those who worked at home was "sometimes" higher, but did not increase much in these years (from $7.7 \%$ to $10.8 \%$ ).

Figure 1 shows the percentage of employees that started to work from home because of the COVID-19 situation in Europe. 
The figure shows 'Yes' for respondents in the EU27 when asked: Have you started to work from home as a result of the COVID-19 situation? Slovenia is excluded from the data for this question because of a translation issue.

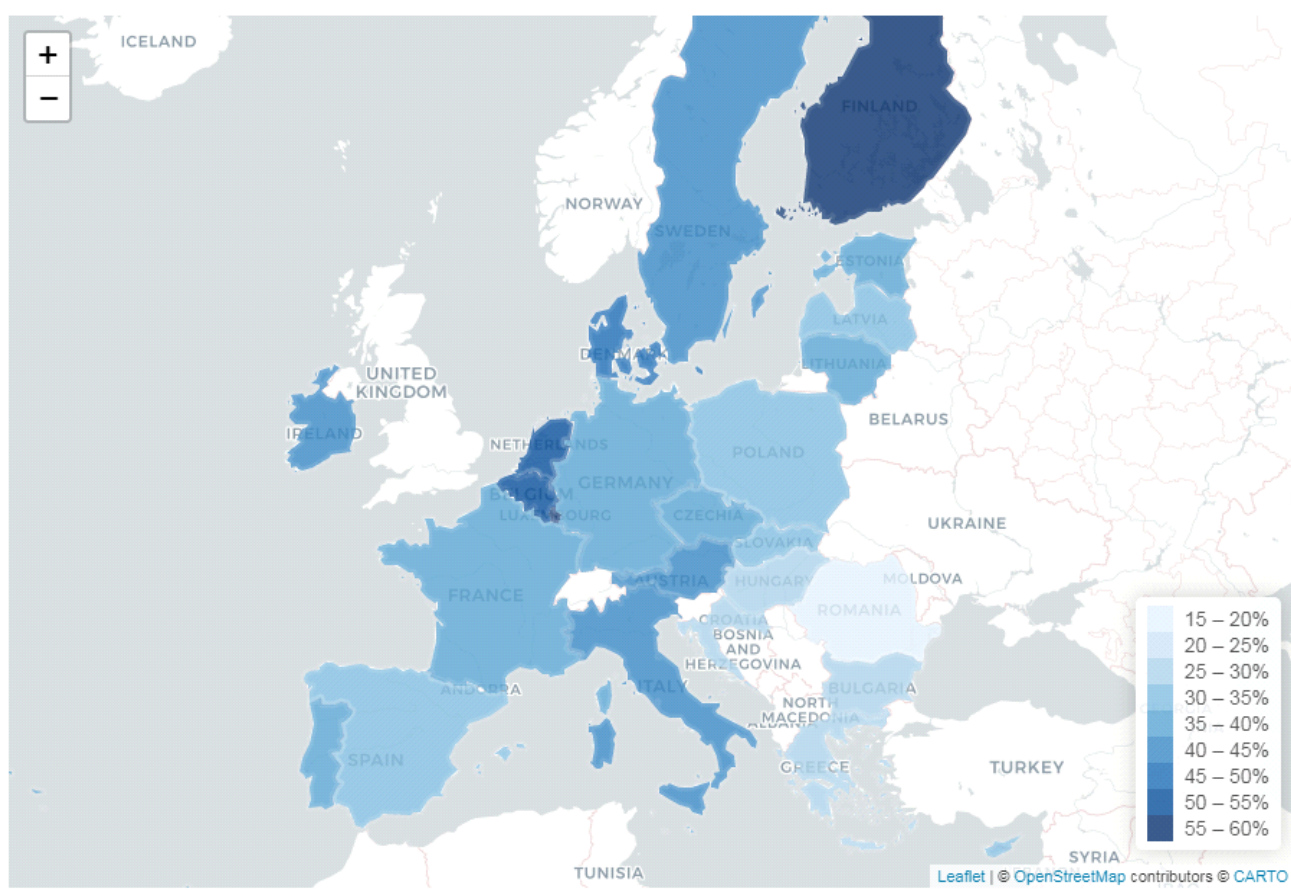

Figure 1. Teleworking in Europe as a result of the coronavirus crisis.

A comparison between these data presents several limitations related to the definition of teleworkers and the questions included in each survey. However, in general terms, it can be affirmed that the coronavirus crisis led to a huge increase in teleworking, from $3 \%$ to around $40 \%$ of workers. On average, $36.8 \%$ of employees started to work from home, and the percentage reached 59\% in Finland, 56.8\% in Luxembourg, 53.9\% in the Netherlands, and $53.4 \%$ in Belgium.

\subsection{ICTs and Digitalisation}

The dataset from the ECS (2019) conducted by the European Foundation for the Improvement of Working and Living Conditions and Cedefop is used to measure the use of ICTs within companies across Europe and levels of innovation. Digitalisation and innovation are measured in the fourth round of this survey. The dataset includes information from around 20,000 establishments across Europe.

Table 3 shows several variables that characterised the situation in the digitised workplace before the COVID-19 outbreak. Digitalisation refers to data analytics in the production process, the use of data analytics to measure performance, the use of robots, and the use of e-commerce across Europe. Although 49.4\% European establishments used data analytics in their production processes, just $11.6 \%$ used robots to carry out a complex series of actions in 2019 and $28.6 \%$ sold goods or services on the internet. There is therefore more scope for improvement in the digitalisation process according to these data. 
Table 3. Digitalisation and innovation data across Europe in 2019.

\begin{tabular}{|c|c|c|c|c|c|}
\hline Variable & & Mean/\% & SD & Min & $\operatorname{Max}$ \\
\hline \multicolumn{6}{|l|}{ Digitalisation } \\
\hline $\begin{array}{c}\text { Use of data analytics in production } \\
\text { processes }\end{array}$ & $\begin{array}{c}\text { Does this establishment use data analytics to } \\
\text { improve the processes of production or } \\
\text { service delivery? }\end{array}$ & $49.4 \%$ & 0.499 & 0 & 1 \\
\hline $\begin{array}{l}\text { Use of data analytics to measure } \\
\text { performance }\end{array}$ & $\begin{array}{l}\text { Does this establishment use data analytics to } \\
\text { monitor employee performance? }\end{array}$ & $31.5 \%$ & 0.464 & 0 & 1 \\
\hline Use of robots & $\begin{array}{l}\text { Robots are programmable machines that are } \\
\text { capable of carrying out a complex series of actions } \\
\text { automatically, which may include the interaction } \\
\text { with people. Does this establishment use robots? }\end{array}$ & $11.6 \%$ & 0.320 & 0 & 1 \\
\hline Use of e-commerce & $\begin{array}{l}\text { Does this establishment buy or sell gods or } \\
\text { services on the internet? For instance, by using } \\
\text { business-to-business portals, e-commerce, etc. }\end{array}$ & $28.6 \%$ & 0.452 & 0 & 1 \\
\hline \multicolumn{6}{|l|}{$\begin{array}{l}\text { Innovation } \\
\text { Innovation in products and services }\end{array}$} \\
\hline \multirow[t]{6}{*}{ New products and services } & $\begin{array}{l}\text { Is this establishment engaged in the design or } \\
\text { development of new products or services? }\end{array}$ & & & & \\
\hline & $\begin{array}{c}\text { Yes, this is mainly carried out internally at } \\
\text { this establishment }\end{array}$ & $29.91 \%$ & 0.496 & 0 & 1 \\
\hline & $\begin{array}{l}\text { Yes, this is mainly carried out in collaboration with } \\
\text { one or more other establishments within } \\
\text { our company }\end{array}$ & $3.69 \%$ & 0.188 & 0 & 1 \\
\hline & $\begin{array}{c}\text { Yes, this is mainly carried out with one or } \\
\text { more companies }\end{array}$ & $8.70 \%$ & 0.281 & 0 & 1 \\
\hline & Yes, this is mainly contracted out & $2.04 \%$ & 0.141 & 0 & 1 \\
\hline & No & $55.66 \%$ & 0.496 & 0 & 1 \\
\hline Changed products and services & $\begin{array}{l}\text { Since the beginning of 2016, has this establishment } \\
\text { introduced any new or significantly changed } \\
\text { products or services? }\end{array}$ & $34.70 \%$ & 0.476 & 0 & 1 \\
\hline Innovation in processes & $\begin{array}{l}\text { Since the beginning of 2016, has this establishment } \\
\text { introduced any new or significantly processes } \\
\text { either for producing goods or supplying services? }\end{array}$ & $33.50 \%$ & 0.472 & 0 & 1 \\
\hline Organisational marketing innovation & $\begin{array}{c}\text { Since the beginning of 2016, has this establishment } \\
\text { introduced any new or significantly changed } \\
\text { marketing methods? }\end{array}$ & $28.40 \%$ & 0.450 & 0 & $1^{3}$ \\
\hline
\end{tabular}

${ }^{3}$ Source: European Companies Survey (2019).

\subsection{Innovation}

Different types of innovation have been considered: innovation in products and services, innovation in processes, and organisational/marketing innovation [18].

As with the previous subsection, the ECS (2019) is used to present the main data. According to Table 3, European establishments are not innovative. Of the firms surveyed, $71.64 \%$ had not introduced any new marketing methods, $66.40 \%$ had not introduced new products or services, and $55.6 \%$ had not engaged in the design of new products or services since 2016. These data reflect the pre-pandemic scenario, after which the acceleration of digitalisation began to take place through the use of teleworking. Social risks associated with this organisational change are examined in the following section.

\section{Results}

Although teleworking did not increase as expected in the last decade before the pandemic [19], there has been a massive change since then: from around $5 \%$ of usual teleworkers in the EUR-28 before COVID-19, to around 40\% in the EUR-27 during. These results are consistent with the previous literature; Ref. [4] concluded that COVID-19 had resulted in a huge growth in teleworking in Spain, and Ref. [20] showed the same for Lithuania in March 2020. They affirmed that the pandemic crisis has moved millions of workers from offices to homes in a sui generis form of self-isolation.

An increase in the number of people who telework means an increase in the number of workers who will be affected by the associated occupational risks, including greater professional isolation and less organisational commitment on the days when they worked entirely from home. It is important that this issue be urgently addressed, because it will 
become increasingly relevant in a society where the teleworking population has gone from $5 \%$ to $40 \%$.

Before the pandemic, teleworking was characterised by voluntarism, as defined by the European Framework Agreement on Telework. However, this element disappeared as a result of COVID-19; teleworking was adopted by firms as a means of maintaining business continuity, and it was adopted by employees because of safety reasons [4].

The evolution of teleworking can be considered an advanced indicator of greater digitalisation. Firms will need this to survive, and employees will need more digital skills [21]. According to the ECS (2019), levels of innovation and digitalisation were low across Europe in 2019. The use of robots and the use of the internet to sell goods or services were, on average, less than $15 \%$ and $30 \%$, respectively, before the pandemic; however, little change was seen between 2016 and 2019.

\section{Discussion}

Digitisation processes are not neutral; they transform the labour market, how as well as the way we work. This situation implies opportunities and challenges, both in the field of human resources management and in the field of labour market regulation. Regarding occupational risk prevention, digitisation and teleworking have been successful strategies to prevent COVID-19. It is highly likely that, in an environment of accelerated digitalisation and intensive automation, the percentage of teleworking will remain very high, satisfying the legitimate aspirations of improving the well-being and conciliation of a large part of the workers. At the same time, and as a consequence, this contributes to the improvement of the economic results of companies.

However, the success of teleworking as a modality of organising work depends to a large extent on processes that allow mutual trust between the agents to be fostered. This, in turn, requires the deep participation of the affected workers within the framework of a modernised labour relations model. Therefore, it is necessary to develop public and private initiatives to improve training and strengthen strategies for the prevention of occupational hazards in an environment of massive teleworking. In the field of innovation, accelerated digitisation helps to break down barriers faced by innovation processes, by changing the scope of work and leading to significant investment in digital skills training. In this sense, in a post-pandemic environment, the digitalisation drive derived from the coronavirus will strengthen innovation processes. Finally, the coronavirus has highlighted the importance of managing digitisation from a perspective that considers its effect on innovation, developing training and management strategies for European companies.

\section{Conclusions}

COVID-19 has acted as a driver of teleworking. One may wonder whether this virtual way of working might also be a driver of innovation and digitalisation. This section reflects on the process of accelerated change and how it can increase occupational risks, both ergonomic and psychosocial, and how problems detected in the past will be reflected in the new trend of rapid digitalisation. Sustainable work means that more innovation, digitalisation, and digital skills will be required to survive.

Concerning sustainable work, innovation is required to succeed in a digitised context. The coronavirus crisis has affected digitalisation in different ways: innovation in products and services, innovation in processes, and digitalisation in organisation. First, new products and services are necessary to respond to the needs of home confinement and a post-COVID19 society. Second, new processes are required to work digitally and to reduce presentiality or to maintain distances. Third, working in a digitised workplace affects organisational structure and involves organisational innovation. As Ref. [20] note, virtual ways of working bring new challenges to organisations that have had to switch to teleworking. Fourth, changes in marketing methods are required to communicate with customers. In short, innovation is now needed to sustain and foster economic activity in a new, more demanding context. Finally, according to Refs. [22,23], innovation is a strategic dimension and should 
be part of the organisational culture. COVID-19 has made this an even greater requirement for companies.

With regard to the occupational risks of teleworking, the prospects of a substantial boost in the number of workers finding themselves in this mode of work will require the worker's home (or the teleworking premises) to be the workplace, even if they telework only some of the time (i.e., if they combine it with face-to-face work). This situation entails meeting a minimum of requirements at home: an independent and adequate room and other physical conditions in the workplace such as appropriate lighting, temperature, and ventilation, as well as furniture requirements, in particular, an ergonomic chair and table. In addition, appropriate technological equipment (both hardware and software) and connectivity are needed. However, the most substantial occupational risks that remote working can cause come mainly from the protocols that will be applied in terms of control, expecting results, workload, and especially the time that is invested and the way it is distributed. Furthermore, social isolation affects mental health [24]. Stress also increases in telework environments $[25,26]$, particularly when social caring activities are developed while working remotely.

The future of work will be affected by Data Sciences and new social challenges should be faced in this scenario [27].

In short, the present article both bridges a gap in the literature and offers directions for further research in this area [28].

\section{Managerial Implications}

Our article provides three fundamental results for the management of digitisation: (a) teleworking has become a mandatory practice that affects a significant number of employees; this entails an increase in psychosocial risks that should be considered in the design of the business activity; (b) the bottleneck of innovation and digitisation in European companies has been broken with the pandemic, and in this sense a virtuous circle of digitisation, investment and innovation can be produced, supported by integrative strategies that take into account employees' health and safety at work; and (c) the changes produced by teleworking, digitisation, and the incorporation of other technologies such as automation, change the place and the way of working. In this sense, the results of this article show, from a comparative perspective, the opportunity that has been generated by the pandemic, without forgetting to foreground the importance of considering health and safety at work.

\section{Practical/Social Implications}

Our research insights contribute to an understanding of the social challenges (both in terms of sustainable work and occupational risk) that have resulted from the rise in teleworking. Concretely, we refer to sustainable work in the psychological and anthropological sense; not pushing people beyond their breaking point. Government, firm, and employee agreements are needed to meet these challenges. We suggest new models of labour relations based on agreements between firms and employees facilitated by public administrations, so that an environment of teleworking and accelerated digitalisation can be maintained over time.

The redefinition of the home as a working space, the training of employees in digital competences, investment in equipment, the availability of internet connectivity, and the additional issues involved in managing teams remotely are the main challenges in this new scenario. Occupational risks, especially of a psychosocial nature, should be also faced to ensure the well-being of workers.

\section{Limitations and Future Research}

Our research shows the limitations derived from the evolution of the pandemic in the following months. The maintenance of remote work and the use of technology to support 
this work will be considered in the short future. Further research should be focused on the extension of the modality of home-based telework in the different post-pandemic scenarios.

Author Contributions: Conceptualization, A.L.P. and A.E.-G.; methodology, A.E.-G.; software, A.E.G.; validation, A.L.P., F.J.P.G. and D.K.; formal analysis, F.J.P.G.; investigation, A.L.P. and A.E.-G.; resources, F.J.P.G.; data curation, A.E.-G.; writing-original draft preparation, A.L.P. and A.E.-G.; writing-review and editing, A.L.P.; supervision, A.L.P. All authors have read and agreed to the published version of the manuscript.

Funding: This research was funded by Ministerio de Economía, Industria y Competitividad and Fondo Europeo de Desarrollo Regional (FEDER), grant number ECO2017-86305-C4-4-R. The APC was funded by UNED.

Institutional Review Board Statement: Not applicable.

Informed Consent Statement: Not applicable.

Data Availability Statement: https: / / ec.europa.eu/eurostat and https: / /www.eurofound.europa. eu/data/covid-19/working-teleworking (accessed on 10 July 2020).

Conflicts of Interest: The authors declare no conflict of interest. The funders had no role in the design of the study; in the collection, analyses, or interpretation of data; in the writing of the manuscript, or in the decision to publish the results.

\section{References}

1. Eurofound. European Company Survey 2019; Publications Office of the European Union: Luxembourg, 2020.

2. Eurofound. Living, Working and COVID-19 Dataset. Dublin. Available online: http:/ / eurofound.link/COVID19data (accessed on 10 July 2020).

3. Altena, E.; Baglioni, C.; Espie, C.A.; Ellis, J.; Gavriloff, D.; Holzinger, B.; Schlarb, A.; Frase, L.; Jernelöv, S.; Riemann, D. Dealing with sleep problems during home confinement due to the COVID-19 outbreak: Practical recommendations from a task force of the European CBT-I Academy. J. Sleep Res. 2020, e13052. [CrossRef] [PubMed]

4. Belzunegui-Eraso, A.; Erro-Garcés, A. Teleworking in the context of the COVID-19 crisis. Sustainability 2020, 12, 3662. [CrossRef]

5. Hernández de Cos, P. Challenges for the Spanish Economy. Productivity and the Business Sector; Banco de España: Madrid, Spain, 2019.

6. Pinilla García, J.; Nova Melle, P.; Gomiz Pascual, P. Innovative management practices in Spanish companies compared with the EU framework. Rev. Investig. Políticas Sociol. 2018, 17, 1-20. [CrossRef]

7. Si, S.; Ahlstrom, D.; Wei, J.; Cullen, J. Business, entrepreneurship and innovation toward poverty reduction. Entrep. Reg. Dev. 2019, 32, 1-20. [CrossRef]

8. Yu, A.; Si, S. Innovation, internationalization and entrepreneurship: A new venture based study. Innov. Manag. Policy Pract. 2012, 14, 524-539. [CrossRef]

9. Luque Parra, M.; Camargo Rodríguez, A. Teleworking and labor conditions conclusions. IUSLabor 2017, 2, 1-39.

10. Eurostat. Employed Persons Working from Home. 2019. Available online: http://ec.europa.eu/eurostat/web/productsdatasets/- / lfsa_ehomp (accessed on 10 July 2020).

11. Golden, T.D.; Veiga, J.F.; Dino, R.N. The impact of professional isolation on teleworker job performance and turnover intentions: Does time spent teleworking, interacting face-to-face, or having access to communication-enhancing technology matter? J. Appl. Psychol. 2008, 93, 1412-1421. [CrossRef] [PubMed]

12. Murray, W.C.; Rostis, A. Who's running the machine? A theoretical exploration of work stress and burnout of technologically tethered workers. J. Individ. Employ. Rights 2007, 12, 249-263. [CrossRef]

13. Pinilla García, J.; López Peláez, A. The intensification of work in Spain (2007-2011): Teamwork and flexibility. Rev. Española Investig. Sociol. 2017, 160, 79-94. [CrossRef]

14. Tapscott, D. The Digital Economy: Promise and Peril in the Age of Networked Intelligence; McGraw Hill: New York, NY, USA, 1997.

15. Zeruvabel, E. Hidden in Plain Sight. The Social Structure of Irrelevance; Oxford University Press: Oxford, UK, 2015.

16. Osterman, P. How common is workplace transformation and who adopts it? Ind. Labor Relat. Rev. 1994, 47, 173-188. [CrossRef]

17. Eurofound. Working Anytime, Anywhere: The Effects on the World of Work; Publications Office of the European Union, Luxembourg, and the International Labour Office: Geneva, Switzerland, 2017; Available online: https: / /www.eurofound.europa.eu/ publications / report/2017/working-anytime-anywhere-the-effects-on-the-world-of-work (accessed on 10 July 2020).

18. OECD; Eurostat. Oslo Manual: Guidelines for Collecting and Interpreting Innovation Data, 4th ed.; OECD: Paris, France; Eurostat: Luxembourg, 2018.

19. Messenger, J.C.; Gschwind, L. Three generations of Telework: New ICT s and the (R) evolution from Home Office to Virtual Office. New Technol. Work Employ. 2016, 31, 195-208. [CrossRef]

20. Raisiene, A.G.; Rapuano, V.; Varkuleviciute, K.; Stachová, K. Working from home- who is happy? A survey of Lithuania's employees during the COVID-19 quarantine period. Sustainability 2020, 12, 5332. [CrossRef] 
21. Middaugh, E.; Clark, L.S.; Ballard, P.J. Digital media, participatory politics, and positive youth development. Pediatrics 2017, 140 (Suppl. 2), S127-S131. [CrossRef] [PubMed]

22. Morcillo-Ortega, P. La dimensión estratégica de la innovación: Una cuestión de prisma. Dir. Organ. Rev. Dir. Organ. Adm. Empres. 1994, 9, 45-53.

23. Morcillo-Ortega, P. Cultura e innovación en la empresa. In La Dirección de Empresas Ante Los Retos Del Siglo XXI: Homenaje Al Profesor Juan José Renau Piqueras; Universitat de València: València, Spain, 2009; pp. 203-214.

24. Asanov, I.; Flores, F.; McKenzie, D.; Mensmann, M.; Schulte, M. Remote-learning, time-use, and mental health of Ecuadorian high-school students during the COVID-19 quarantine. World Dev. 2021, 138, 105225. [CrossRef]

25. Carillo, K.; Cachat-Rosset, G.; Marsan, J.; Saba, T.; Klarsfeld, A. Adjusting to epidemic-induced telework: Empirical insights from teleworkers in France. Eur. J. Inf. Syst. 2021, 30, 69-88. [CrossRef]

26. Abdel Hadi, S.; Bakker, A.B.; Häusser, J.A. The role of leisure crafting for emotional exhaustion in telework during the COVID-19 pandemic. Anxiety Stress Coping 2021, 34, 530-544. [CrossRef]

27. Saura, J.R.; Palacios-Marqués, D.; Ribeiro-Soriano, D. Digital marketing in SMEs via data-driven strategies: Reviewing the current state of research. J. Small Bus. Manag. 2021, 1-36. [CrossRef]

28. Saura, J.R. Using data sciences in digital marketing: Framework, methods, and performance metrics. J. Innov. Knowl. 2021, 6, 92-102. [CrossRef] 